\title{
Critical Analysis of Slum Tourism: A Retrospective on Bangalore
}

\author{
Neha Itty Jose Paul ${ }^{*}$
}

\section{Abstract:}

Slum tourism is a relatively unknown and controversial niche tourism segment. This form of tourism is mainly found in small pockets around the so-called third world. Slum tourism is famous in the Kibera slum in Nairobi and the Rochina slum in Rio de Janeiro. The largest slum in Asia, the Dharavi slum, became popular notably through the release of the Oscar-winning movie "Slumdog Millionaire" which highlighted the slum in Mumbai and thus brought the much-needed limelight on slum tourism otherwise known as poverty tourism. Slum tourism is the act of visiting low-income settlements also known as Favelas or simply as slums. Slum tourism has received mixed reviews of both a positive and negative character. A negative approach due to the very reason of it being seen as a means of showcasing the poor for the benefit of inquisitive tourists and critics say this form of tourism is voyeuristic and leads to the ill-treatment of slum dwellers. However, slum tourism can also lead to positive outcomes if managed in a sustainable manner it can develop employment opportunities for the slum dwellers. This paper deals with whether or not slum tourism has the potential of being developed in Bangalore, to find out if the much hype about slum tourism in Mumbai has created any demand for this niche market in Bangalore. A

* Lecturer, Department of Travel and Tourism, Mount Carmel College (Autonomous),Bengaluru, India; nehaijpaul@gmail.com 
quantitative research methodology is used to investigate the matter. A survey and correlation analysis were conducted to delve into slum tours perspective of customers and travel agents of Bangalore. Findings of the study reveal that the potential customers or tourists are keen on taking such tours where as travel agents do not conduct slum tours as the profit margins are low.

Keywords: Slum tourism, poor tourism, community development, Bangalore

\section{Introduction}

Travel and tourism are often claimed to be the world's largest industry; there is no doubting the enormous global economic value of travel and tourism, according to Sharpley (n.d.).The concept of modern tourism, as we understand it today is relatively new, not more than sixty years old, according toSeth and Bhat. The concept of tourism has not only become a major force in world trade but also a vital factor in a country's economic, cultural and social development (Batia, 2002). Tourism is now a global trend that has been facilitated by the ever growing technological advancements, innovations, new forms of tourist attractions and emerging tourism related businesses. Therefore,Seth and Bhat say it is a new economic phenomenon, a new business, a new industry of vast dimensions and magnitude.

During the last decade of the 20th Century, a form of mass tourism emerged in the major cities of several developing countries involving visits to the most disadvantaged parts of the respective city - the slums(Obrien, 2011). There are various forms of tourism and slum tourism is one such branch of dark tourism. Most are familiar with the word "tourism", but "slum tourism" or "poor tourism" is a new concept whichis a part of leisure tourism. There are several variants to "slum tourism" such as "SlumdogTourism," "poverty safaris," and "ghetto tourism." Poverty safaris are visits to places like the Millennium Villages in Rwanda and so on. Ghetto tours are all forms of entertainment that allow consumers for trafficking in the inner city without leaving home. "Poverty porn" (also known as "development porn" and "famine porn") is any media that exploits the conditions of the poor in order to generate 
the necessary sympathy for increasing charitable donations, support for a given cause, or just for selling newspapers. "Disaster tours" are travel to visit the scene of a natural disaster (Ausland as cited in Obrien, 2011). These poverty tours or slum tours are offered on a relatively large scale in the favelas of Rio de Janeiro in Brazil and in the slums of India (as mentioned in the magazine on Mumbai's Dharavi Slum). Tour operators also offer slum tours in the shantytowns of such African cities as Nairobi, Johannesburg, and Cape Town, and in the towns of Asian cities like New Delhi and Jakarta. The target market for these slum tours primarily consists of international tourists. Rolfes (2010) stated that an estimated 40,000 slum tourists visit Rocinha each year and that around 3,00,000 visit the townships in Cape Town.

Slum tourism is a type of tourism that involves visiting impoverished areas, which has become increasingly prominent in several developing countries like India, Brazil, Kenya, Mexico, South Africa and Indonesia. On the contrary Slum tourism is not limited to the developing world as slum tours exist in such cities as Toronto.Obrien(2011) mentions that it is only during the last decade of the 20th Century, a form of mass tourism emerged in the major cities of several developing countries involving visits to the most disadvantaged parts of the respective city - the slums. The United Nations Human Settlements Program, the UN agency responsible for human settlements, noted that slums are a physical and spatial manifestation of urban poverty.

Therefore, the phenomenon of slum tourism has spread to new areas. In April 2010, a local tourism operator -Asian Trails announced that it was going to organize tours every Wednesday of Klong Toey (Bangkok's largest slum) and the Duang Prateep Foundation. The Klong Toey slum has existed for some 50 years and its inhabitants largely are rural migrants from northeast Thailand who came to Bangkok for job opportunities. The Duang Prateep Foundation primarily focuses on helping urban poor populations, with special emphases on community development and on giving the best possible opportunities to the area's children. Slum tourism, like slums and poverty, is not limited to the developing world, however, and slum tours exist in such cities as Toronto. The idea of 'slumming' has spread beyond visits to the 
slums of major cities. In Croatia, for example, tourists can go slumming in the Roma community. So slum tourism can be traced to several regions around the world. This would lead to the pertinent question as to when did the phenomenon originate?

\section{Origin of Slum Tourism:}

Slum tourism is a type of tourism that involves visiting impoverished areas, which has become increasingly prominent in several developing countries like India, Brazil, Kenya, Mexico, South Africa and Indonesia. The roots of slum tourism can be traced back to 1884 when the Oxford English Dictionary first recognised the term "slumming it". Tourists visited neighbourhoods such as Whitechapel in London or the Lower East Side in New York to "see how the other half lived" (Loftus as cited in Delic, 2011). These areas were not necessarily as extreme as the slums that can be found on the outskirts of major cities presently, but at the time, they were considered the poorest locations and sparked interest among the wealthy, the same demographic most interested today.

For the next hundred years, there were no organized tourism strategies for slum tourism. Instead, regions mostly in the Global South, trying to develop their economy took on a "slum clearance" strategy. The slums were seen as dirty and an "eyesore" to major cities who were trying to attract tourists. Governments put money into removing them from the city borders. The rationale was that tourists would not want to come to cities that were associated with slums, primarily due to safety issues and a lack of cleanliness (Freire - Medeiros, 2008). Although the popularity of slum tourism is on the rise, the niche still faces these concerns from some people today.

\section{Review of Literature:}

\section{Growth in Slum Tourism:}

Most of us are familiar with the word 'tourism', but 'slum tourism' or 'poorism' is a new subject. Slum tourism is: "Poverty tourism or poorism, also known as township tourism or slumming, is a type of tourism, in which tourists travel to less-developed places to 
observe people living in poverty." According to slum tour operators, tourists use this as an opportunity to learn about real slum life.One of the most popular slum tour organizations is Favela Tours which has seen an average of 3,000 tourists per month for the past ten years. A total of 98 percent of its market is foreigners, a trend seen across all organized slum tours (Freire - Medeiros, 2008). Hence the niche market is expanding tremendously and can be introduced in various parts of India also.

\section{Advantages of Slum Tourism in communities across the world:}

Miles (2005) explores the means through which tourism can help benefit the local communities in Africa. The paper questions on whether tourism does much to alleviate poverty? The articles stress on the fact that much of the infrastructure in East Africa is thanks to tourism. Without tourism, Africa would be in a very sorry state. The report by Ziegler (1999) defines pro-poor tourism in general terms as tourism that generates net benefits for the poor. As there are several reasons for focusing efforts on developing pro-poor tourism; one of the compelling reasons is that the tourism industry being a massive and growing industry it has advantages over other economic sectors in relation to poverty elimination. Tourism would indirectly benefit the poor and drastically reduce the costs they face.

Frenzel (2012) talks about the unusual form of tourism that is becoming increasingly popular not only in countries like Brazil, India and South Africa but also in several cities across the globe. The study investigates into the aspects how slum tourism would be advantageous to the community. Similarly, Nevin (2007) highlights on how the benefits of slum tourism will help resolve financial problems of the community and result in poverty alleviation of the slum residents. He says that 'Pro-poor' Tourism addresses the big debate that surrounds the role of tourism as an effective means of development. The article focuses on the slum tours conducted in Nairobi, where Victoria Safaris offer Kenya Slum Tours and brings out details of a visit of some of the city's millions of shanty town dwellers. This noble idea is a means of creating awareness of the plight of the poor in Kenya to both foreign and domestic tourists. The intention is to wipe out the slums in Africa and Kenya in particular as a long-term measure by using the tourism business. 


\section{Criticism on Slum Tourism:}

From the perspective of tourists, Lisser (2003) gives a brief on why travellers are intrigued by this unique from of tourism. According to Lisser (2003), travellers these days exhibit a "been-there, donethat" mentality, "explore the unexplored" providing the tour operators around the world to make arrangements for the provision of this form of tourism.Many may see this as voyeuristic and exploitive and a spark for potential misunderstandings, if not outright exploitation. Slum tours, in Netherlands initially encountered stiff resistance from some residents and local officials. The criticism was that the tour, made the residents feel like they were be watched ad they felt intruded. Many cities offer tours of neighbourhoods traditionally shunned by tourists, such as Philadelphia Neighborhood Tours emphasising on music and food where visitors can sample Laotian food or learn the difference between salsa and samba. The Black Paris Tours focus on AfricanAmerican and African history/influences in Paris. Favela tours in Rio de Janeiro have a three-hour escorted tour of one of Rio de Janeiro's shantytowns.

\section{The condition of Slums across India:}

The situation of slums in Indiais covered in the article titled "Major slum areas";it covers metropolitan cities slum areas and the drawbacks they face there. Slum areas always lack some necessities of life like clean water, electricity and sanitation. The inhabitants are mostly rickshaw pullers, small seasonal vendors, house maid servants with a family income ranging from a meagre Rs.1500 to Rs.3000. The slum population is constantly increasing: it has doubled in the past two decades. The current population living in slums in the country is more than the population of Britain. The top cities covered in the article are Dharavi Slum, Mumbai; Bhalswa Slum,Delhi; Nochikuppam Slum, Chennai; Basanti Slum, Kolkata; Rajendra Nagar Slum, Bangalore; Indira Nagar, Hyderabad; Mehbullahpur Slum, Lucknow; Satnami Nagar Slum, Bhopal and Parivartan Slum, Ahmadabad. Delhi Government has proposed to launch a survey to prepare a database of slum dwellers in the city to help them but otherwise very little is being done to assist these slum dwellers. Hence the question can be raised if slum tourism 
can be introduced to eliminate poverty and make the slum selfsustaining?

\section{Slum Tourism in India:}

Delic (2011) discusses the historical development of slum tourism in India; it gained momentum after the release of the Oscarwinning movie "Slumdog Millionaire". The paper further looks into the controversies that slum tourism faced in the global scenario. Some argue that one of the reasons poverty still exists is because people are too far away from it geographically and mentally. However, on looking into the brighter side of affairs slum tourism can be used as a means of educating people and creating awareness of the less fortunate, it does not depict poverty as entertaining, but showcases the truth and thus can be considered as reality tourism.

The article by Shah (2006) describes slum tourism or 'poorism' quickly becoming 'incredible' India's newest crowd-puller. There are various slum tours conducted in India, the Reality Tours and Travels of Mumbai conducts a four-and-half-hour tour through Asia's largest slum Dharavi. It was inspired by the popular walking tours of Brazil's infamous favelas and bus tours of South Africa's black shanty towns. Other than this there are tours conducted in Delhi by Salaam Baalak Trust, a charitable organization which conducts tours into the life of street children at New Delhi railway station. Other tours conducted by Semester-at-Sea, a Chennai-based company that holds 'reality-based' education programme tour of the Nampet Choolaimedu slum. The tourists who usually undertake these tours belong to the upper-middle class, and consist of western students, researchers, academics and church-groups these tourists are bored of standard Mughal architecture-and-sand dunes India tour. They want to experience the so-called 'real' India and see in person the adverse conditions that people live in. There are several monetary benefits that the slum community derives off these tours as Reality Tours and Travels contributes eighty percent of their profits to the into MESCO, an NGO that works with slumdwellers. Salaam Baalak Trust puts the entire Rs 200 earned per tourist towards the rehabilitation of street children. Surprisingly, 
those being 'toured' the slum dwellers and the street children seem to have few issues about the tours.

In a field study conducted by Yarmuch (2010) in Dharavi slum Mumbaiit was proved that slum tourism could contribute toward poverty alleviation by funding schools and other projects.

\section{Comparison of Slum Tours conducted in India versus other Countries:}

In India, slum tourism takes the form of creating the awareness of poverty that exists in Dharavi Slum, India. In South Africa, it takes a turn into historical injustice as well as ethnic and cultural uniqueness, while in Rio's favela tours poverty translates into community and solidarity. Thus, the way slum tourism is packaged differs with aparticular focus on the way representations are crafted by professionals in the field (Frenzel \& Koens, 2012). "Slum tours" are big business in Mumbai's Dharavi, driven by curious eyes from abroad (Zaidi, 2012). Rolfes (2010)suggests that the aims of these tours are deliberate sightseeing and the explicit demonstrations of poverty. Whyte, Selinger and Outterson (2011) question the morality of the financially privileged tourists to visit places for the purpose of experiencing where poor people live, work, and play. While for some poverty tourism is plausible ethically, other practices will be more controversial.

\section{Slum Tours in Dharavi:}

Slum tourism existed in Mumbai, India long before 'Slumdog Millionaire,' a 2008 Oscar winning movie, after which it came to the highlight. The slums are very much a part of - some would say the foundation of - Mumbai city life. An astonishing 55 percent of Mumbai's population lives in shantytowns and slums, and the largest slum in Mumbai (and Asia, for that matter) is Dharavi.

Originally inhabited by fisher folk when the area was still creeks, swamps and islands, it became attractive to migrant workers, from South Mumbai and beyond, when the swamp began to fill in as a result of natural and artificial causes. It now incorporates $1.75 \mathrm{sq}$ $\mathrm{km}$ sandwiched between Mumbai's two major railway lines and is home to more than one million people. While it may look a bit shambolic from the outside, the maze of dusty alleys and sewer- 
lined streets of this city within a city are a collection of abutting settlements. Some parts of Dharavi have mixed populations, but in others inhabitants from different parts of India, and with various trades, have set up homes and tiny factories. Potters from Saurashtra live in one area, Muslim tanners in another; embroidery workers from Uttar Pradesh work alongside metalsmiths; while other workers recycle plastics as women dry pappadams in the searing sun. Some of these thriving industries, some 10,000 in all, export their wares, and the annual turnover of business from Dharavi is thought to top a remarkable US\$665 million. Up close, life in the slums is strikingly normal. Residents pay rent, most houses have kitchens and electricity, and building materials range from flimsy corrugated-iron shacks to permanent multi-storey concrete structures. Many families have been here for generations, and some of the younger Dharavi residents even work in whitecollar jobs. They often choose to stay, though, in the neighbourhood they grew up in.

Slum tourism is a polarising subject, so you'll have to decide your feelings for yourself. If you opt to visit, Reality Tours \& Travel does a fascinating tour, and pours a percentage of profits back into Dharavi, setting up community centres and schools. Some tourists opt to visit on their own, which is okay as well - just don't take photos. Take the train from Churchgate station to Mahim, exit on the west side and cross the bridge to Dharavi.Reality Tours and Travel was named anOverallwinner. Established in 2005, Reality Tours had 10,000 guests last year. They offer city and village tours in Mumbai and beyond, this Award is for their educational Dharavi Slum Tours. In recent years' slum tourism has become increasingly popular, and increasingly controversial. Reality's tours aim to be an educational look at the strengths, opportunities, challenges and issues of life in the Dharavi community.They donate 80 percent of post-tax profits to their sister NGO, Reality Gives. Reality Gives provides educational programmes for residents of Dharavi, and supports some micro-enterprise and community initiatives including sports, beekeeping, and youth empowerment programmes. 


\section{Slum Tourism in Bangalore:}

In recent decades Bangalore has drawn attention not only as an IT hub but also for its high profile development of cutting edge industries like Bio-Tech, the presence of a large number of multinational companies, international finance and global consumerist trends (Chowdhury, n.d.). However, despite this growth,the downside is the rise in slums in and around the city. Bangalore alone holds 570 slums from atotal of around 2000 slums in Karnataka. It is estimated that about 20 percent of Bangalore population reside in slums.

By introducing tourism, urban employment is created within this tertiary sector, as in hotels and restaurants, drivers of the fleets of rental taxis which serve the new international airport, security and maintenance personnel in malls and supermarkets, low end jobs in taxi/travel agencies (office boys), waiters and other support staff in the expanding hospitality industry as well as slum walk guides.Dr Frenzel, a lecturer in the Political Economy of Organization at the School of Management, University of Leicester, has observed that "This form of tourism might seem unusual, but in recent years more and more visitors have taken tours in slums, predominantly in South Africa, Brazil and India, but increasingly also in other cities across the world." Thus Bangalore has the potential of developing poor tourism and if managed efficiently can result in employment generation and also thedevelopment of slums resulting in poverty alleviation.

\section{Need for the Study:}

Few or rather no research has been conducted on slum tourism, especially with aspecial focus on Bangalore. Studies have been conducted on Dharavi Slum in Mumbai and slums in Delhi. If slum tourism does not exist in Bangalore to find out if there is a possibility of developing it by finding out a prospective tourist who would like to visit and whether travel agent and tour operators would promote this form of tourism.

\section{Statement of Problem:}

The reason for choosing this topic for the study is because Bangalore alone holds 570 slums froma total of around 2000 slums 
in Karnataka. These slums have been ignored through the decades and have been allowed to rapidly grow in an unstructured manner. Thus, the purpose of this research is to find out if slum tourism exists in Bangalore and if not is it feasible to introduce the concept into Bangalore. Would thecustomers be interested in undertaking this form of niche tourism and if so would this benefit the slums in any manner.

\section{Scope of the Study:}

The study conducted is restricted to Bangalore, where there is a plethoraof large scale, medium scale and small scaletravel agencies such as Thomas Cook, Cox and Kings, SOTC, Hammock Leisure Holidays and numerous other such travel agencies that offer customised and internationally recognised customer service. Also, there is a large market of potential tourists in Bangalore which makes it an apt area for conducting the research.

\section{Objective:}

To find out if Bangalore has the potentiality to be developed as a slum tourism destination

\section{Sources of Data Collection:}

Both primary and secondary modes of data collection are used for this study. Primary data was collected by the researcher through a survey and interview method. The data was collectedusing a structured questionnaire. The secondary data was collected from articles, journals, newspapers and so on.

\section{Sampling technique:}

The sampling technique used is non-probability sampling, under which convenience sampling has been used to collect data from the expected target audience.

\section{Sampling Size:}

Travel agents -60

\begin{tabular}{|c|c|c|}
\hline Small & Medium & Large \\
\hline 20 & 20 & 20 \\
\hline
\end{tabular}


Customers -60

\begin{tabular}{|c|c|c|}
\hline Travel agent's customers & Students & Others \\
\hline 20 & 20 & 20 \\
\hline
\end{tabular}

\section{Techniques of Data Analysis:}

Statistical techniques of T-test, thecorrelation in the bivariate have been used to analyse the data.

\section{Pilot Study and Reliability test:}

The objectives of the study were identified, based on which the questionnaire was developed.The questionnaire made use of the Likert Scale.The questionnaire was validated, following which the Pilot Study was conducted.The responses were coded and then subjected to the Cronbach Alpha Reliability Test.The reliability was found to be 0.786 was obtained for travel agents and .609 for customers.

\begin{tabular}{|c|c|}
\hline \multicolumn{2}{|c|}{ Reliability Statistics - Travel Agents } \\
\hline Cronbach's Alpha & N of Items \\
\hline .786 & 19 \\
\hline
\end{tabular}

\begin{tabular}{|c|c|}
\hline \multicolumn{2}{|c|}{ Reliability Statistics Customers } \\
\hline Cronbach's Alpha & N of Items \\
\hline .609 & 14 \\
\hline
\end{tabular}

\section{Hypothesis:}

H0: No significant relationship between the potentiality to develop slum tourism in Bangalore and travel agents interest to conduct slum tours. 


\begin{tabular}{|l|c|c|c|}
\hline \multicolumn{4}{|c|}{ Correlation } \\
\hline \multirow{3}{*}{ Interest } & & Interest & Develop \\
\cline { 2 - 4 } & Pearson Correlation & 1 & .190 \\
\cline { 2 - 4 } & Sig. (2-tailed) & & .147 \\
\cline { 2 - 4 } & $\mathrm{N}$ & 60 & 60 \\
\hline \multirow{3}{*}{ Develop } & Pearson Correlation & .190 & 1 \\
\cline { 2 - 4 } & Sig. (2-tailed) & .147 & 60 \\
\cline { 2 - 4 } & $\mathrm{N}$ & 60 & \\
\hline
\end{tabular}

Interpretation: The above table indicates that there exists a positive correlation $(\mathrm{r}=.190)$ between potentiality to develop slum tourism and travel agents interest. The $p$ value of .147indicates that the relationship between the two variables is not significant. Therefore, the null hypothesis that there is no significant correlation between publicity and customers' influence to undertake slum tours is accepted. Hence the travel agents are not keen on introducing the concept in the city of Bangalore. The interviews with the travel agents showed that the monetary benefit of this form of tourism is low hence they seemed disinterested in engaging in Slum tourism.

\section{Major Findings of the Survey:}

a) The surveydiscovered that the travel agents agreed the there is a potentiality to develop slum tours in the city as almost 50 percent of them completely agree or agree to this fact.

Slum tourism's potentiality to develop in Bangalore

\begin{tabular}{|l|c|c|}
\hline \multicolumn{1}{|c|}{ Potentiality to develop } & Frequency & Percent \\
\hline Completely disagree & 2 & 3.3 \\
\hline Disagree & 8 & 13.3 \\
\hline Neither agree nor disagree & 19 & 31.7 \\
\hline Agree & 22 & 36.7 \\
\hline Completely agree & 9 & 15.0 \\
\hline Total & 60 & 100.0 \\
\hline
\end{tabular}

The survey also revealed that customers were motivated to take slum tours on as a part ofVoluntourism(volunteer tourism) to 
contribute to the welfare of slum residents. The study shows that almost 60 percent found that to be very influential or extremely influential.

Customers motivation to take up a slum tour due to:Contribute towards welfare of slum residents

\begin{tabular}{|l|c|c|}
\hline \multicolumn{1}{|c|}{ Contribute } & Frequency & Percent \\
\hline Not at all Influential & 12 & 20 \\
\hline Slightly Influential & 12 & 20 \\
\hline Moderately Influential & 0 & 0 \\
\hline Very Influential & 12 & 20 \\
\hline Extremely Influential & 24 & 40 \\
\hline Total & 60 & 100 \\
\hline
\end{tabular}

b) The study also investigated if customers would approach travel agents to conduct such tours for them; it was found that majority of the customer would approach atravel agent to go for slum tours. Of this, 40 percent of the customers prefer to go on a guided tour through a travel agency.

Slum tour - would customers approach travel agent(s)

\begin{tabular}{|l|c|c|}
\hline Approach Travel agent(s) & Frequency & Percent \\
\hline Not at all probable & 25 & 41.66667 \\
\hline Slightly probable & 0 & 0 \\
\hline Moderately probable & 0 & 0 \\
\hline Very probable & 24 & 40 \\
\hline Completely probable & 11 & 18.33333 \\
\hline Total & 60 & 100 \\
\hline
\end{tabular}

\section{Summary of Findings:}

Slum tourism is indeed a controversial subject thus it has to be dealt delicately with a lot of research and foresight. Thus if introduced in a sustainable manner it would result in employment generation, upliftment of the slums, create more awareness amongst people and sensitise them on the importance of poverty alleviation. As people live in ignorance of a world that exists beyond the metropolitan life, it would open an avenue for the slum dweller to address their issues and eventually result in the eradication of slums. It is also beneficial to the travel agents since 
they will be able to tap an unexplored market that is less competitive.The main aim of the study was to find out the prospects and potentialities of introducing this concept of slum tourism in Bangalore. The potential tourists are keen on undertaking slum tours and also are interested in approaching travel agents and tour operators for organising the same. Interestingly even though the travel agents find that there is potential in developing slum tours in the city, they hesitate to conduct them with a perspective on the profit that can be madeon the tour.Therefore, as there is customer interest in the market forthistour,travel agents may consider undertaking it or can involve slum dwellers who can initiate such tours with the assistance of NGOs and Government.

Slum tourism is a relatively new concept and is still being extensively researched on. There are several benefits of slum tourism and the main focus is to eventually eradicate slum or rather help in providing better living conditions. In recent studies, it has been found that there has been a significant participation of government bodies in supporting slum tourism, the concept of propoor tourism has resulted in several advantages such as economic benefits, employment opportunities and, on the whole, ahealthy balance between the rich and the poor.

\section{Criticism:}

Slum tourism has been the subject of much controversy. Both critiques and defences of the practice have been made in the editorial pages of prominent newspapers, such as the New York Times, Wall Street Journal, London Times, and others. Accusations of the industry include that it "turns poverty into entertainment, something that can be momentarily experienced and then escaped from." The London Times columnist Alice Miles labelled the movie Slumdog Millionaire as "poverty porn" because of what she considered abuse of the real poverty of individuals for the sake of entertainment (Selinger \& Outterson, 2009). David Fennell, professor of tourism and environment at Brock University, claims that the tours help wealthy Westerners to feel better about themselves. He cites as proof that the slum tourism spike often happens during the Holiday Christmas season, and the first half of 
February prior to Valentine's Day (Weiner, 2008). Many such tourists are without family on Christmas or significant others on Valentines.

Proponents of slum tourism say it benefits all parties involved. Others argue that criticism is anecdotal, rather than based on research or scholarship. The tours provide employment and income for tour guides from the slums, an opportunity for craft-workers to sell souvenirs, and may invest back in the community with profit that is earned. As the debate over the ethics of slum tourism continues, studies are being done. Forums for discussion are being created to further the dialogue and provide reliable information.

\section{Contemporary Slum Tourism: The Pros and Cons}

Harold Goodwin, director of ICRT and one of the originators of Pro-Poor Tourism, notes that ignoring poverty will not make it go away and that "Tourism is one of the few ways that you or I are ever going to understand what poverty means. To just kind of turn a blind eye and pretend that poverty does notexist seemsto me a very denial of our humanity" (quoted in Weiner, 2008).Obrien (2011) says that the critics of twenty-firstcentury slum tourism see slum tourism as controversial for two main reasons that have given rise to accusations that the tours are exploitative and imperialistic. The first reason is that private, for-profit companies, most of which do not put money back into the slums, run slum tours. The second reason is that slum tourism is said to be a voyeuristic and dehumanising approach to travel in poor communities.

Critics claim that it is an invasion of people's privacy and humiliating taking away of the dignity of the poor. They claim that slum tourism objectifies the poor and treats them like exhibits in a zoo as it displays the destitute lifestyles of slum residents to predominantly white, wealthy, Western tourists. Critics also see slum tourism as just another example of tourism operators finding a new niche market to exploit.In return, slum tour operators argue that they are trying to bring awareness (and in some cases cash) to the areas, to educate tourists about the reality of poverty and, especially, to dispel negative stereotypes surrounding slum residents. A small number of operators have even built schools or 
community centres in the slums. One example is Reality Tours and Travel, which runs tours of Dharavi, Mumbai's largest slum.

Reality Tours and Travel claims that this part of the company is not run for profitablepurposes and that the money from the tours goes to support the activities of the sister organisation.A nonprofit children's charity, the Salaam Baalak Trust, offers visitors to New Delhi a slum tour of the area around the inner city of Paharganj and the New Delhi railway station where more than 2,000 street children live. The two-hour walks are chaperoned by former street children themselves, who know the routes and the necessary survival methods all too well. The "city tours,' as they are called, started in2006, but the organization itself was founded in 1989 by the celebrated Indian filmmaker Mira Nair, director of the 1988 movie Salaam Bombay(a film about street life in India), to rehabilitate the street children who appeared in the film (Salaambalaaktrust, n.d., cited in Obrien, 2011). Weiner (2008) reported that at least some of the tourists who have been on slum tours claimed the experience changed their lives.Therefore, there is a positive side to this form of tourism which can be adopted into Bangalore.

\section{Conclusion:}

There is a ray of potentiality to introduce and develop slum tourism as there is a relatively interested market in Bangalore. However, as it is a fairly new concept, the travel agents are hesitant to take the first step and introduce it as there are several possibilities of it not being successful. On the other hand, there is prospective clientele that exists in the market the large scale travel agencies should venture out and experiment with this concept. Indeed, Slum tourism lacks clarity and would appeal only to a select few tourists. On the other hand, if these tours are conducted with the purpose of eradicating slums and bring in development the government might show interest in supporting this concept. Therefore, slum tourism has a potential to grow provided the travel agents take the initiative and encourage its growth. 


\section{Reference:}

Batia, A. K. (2002). Tourism development principles and practices. (2nd ed.). New Delhi, India: Sterling Publishers Pvt Ltd.

Chowdhury, S. R. (n.d.). Livelihood and Income: Informality and poverty in Bangalore's slums. Retrieved from http:// www.southasia.ox.ac.uk/sites/sias/files/documents/Oxford University CSASP - Work in Progress paper 10 Supriya RoyChowdhury.pdf

Delic, J. M. (2011). Trends in slum tourism. Unpublished raw data, School of Hospitality and Tourism Management, University of Guelph, Retrieved from https:// www.google.co.in/url?sa $=t \& r c t=j \& q=\& e s r c=s \&$ source $=w e b \& c$ $\mathrm{d}=1 \&$ cad=rja\&ved=0CDMQFjAA\&url=http:/ / atrium.lib.uogue lph.ca/xmlui/bitstream/handle/10214/2585/Slum_Tourism_T rend_Paper.doc?sequence $=4 \&$ ei $=7 \mathrm{MhAUf6XB8TIrQfd6YHIBQ}$ \&usg=AFQjCNGzhKev8UfZSxSw5tSliwk_REeQ\&sig2=Zc0gCt qNMXNB59Fp2zbtgA\&bvm=bv.43287494,d.bmk

Freire - Medeiros, B. (2008). The favela and its touristic transits. [Electronic version]. Geoforum, 40(2), $580-588$.

Frenzel , F., \&Koens , K. ( 2012). Slum Tourism: Developments in a YoungField of InterdisciplinaryTourismResearch. Tourism Geographies: An International Journal of Tourism Space, Place and Environment, 14 (2), 195-212. Retrieved from http:// dx.doi.org/10.1080/14616688.2012.633222

Frenzel, F. (2012). University of Leichester; 'Slum Tourism' research project launched at University of Leichester. Entertainment Newsweekly. Atlanta, United States ofAmerica:NewsRx.ttp:// www.nytimes.com/2008/03/09/travel/09heads.html?pagewa nted=all\&_r $=0$

Major slum areas in top ten cities of India. (n.d.). Magazine article. Retrieved from http://www.walkthroughindia.com/ lifestyle/ major-slum-areas-in-top-indian-cities/

Nevin, T. (2007). What is pro-poor tourism? African Business, 5052.

OBrien, P. W. (2011). Business, management and poverty reduction: A role for slumtourism. Journal of Business Diversity, 11(1), 33-45. Rolfes, M. (2010). Poverty tourism: theoretical reflections and empirical findings regarding an extraordinary form of tourism. GeoJournal, 75, 421-442. doi: 10.1007/s10708-009-9311-8 
Selinger, E., \&Outterson, K. (2009). The ethics of poverty tourism. Unpublished raw data,Boston University School of Law, Boston, Retrieved from http://www.bu.edu/law/ faculty/ scholarship/workingpapers/2009.html

Seth, P. N., \& Bhat, S. S. An introduction to travel and tourism. $3^{\text {rd }}$ Edition. Sterling Publishers Pvt Ltd

Shah, R. (2006, October 9). Sun, Sand And Slums; With slum tourism becoming the latest exotica, India's poverty-ridden underbelly is getting dollar-rich visitors. 76 .

Sharpley, R. Travel and tourism . SAGE Publication India Pvt Ltd

Weiner, E. (2008). SlumVisits: Tourism or voyeurism?. The New York Times.

Whyte, K. P., Selinger, E., \&Outterson, K. (2011). Poverty tourism and the problem ofconsent.Journal of Global Ethics, 7(3), 337-348. doi: 10.1080/17449626.2011.635689

Yarmuch, K. (2010). Slum tourism: Dharavi. Unpublished raw data, Royal Roads University.

Zaidi, A. (2012, September 02). Slumgawkmillionaires.The Sunday Guardian. Retrieved from http://www.sundayguardian.com/artbeat/slumgawk-millionaires

Ziegler, C. A. (1999). Sustainable Tourism and Poverty Elimination Study. London: Deloitte \&Touche: Oliver Bennett, International Institute for Environment and Development (IIED): Dilys Roe,Overseas Development Institute (ODI): Caroline Ashley. 